The Chittagong Univ. J. Sci. 42(1): 84-98, 2020

Short communication

\title{
Organic Carbon Concentration in the Soils of Coastal Afforestation Sites in Bogachattor, Chittagong
}

\author{
Md. Danesh Miah* and Sisile Chowdhury \\ Institute of Forestry and Environmental Sciences, University of Chittagong, Chittagong 4331, \\ Bangladesh \\ *Corresponding author; E-mail: dansmiah@gmail.com, danesh@cu.ac.bd
}

Manuscript received on 19 August, 2019, Revised manuscript received on 15 March, 2020 and accepted on 01 November, 2020.

DOI: https://doi.org/10.3329/cujs.v42i1.54239

Global climate change is one of the burning issues of the present time, where carbon has a critical role to play [1]. Coastal afforestation plays an essential role in reducing the impact of climate change. Bangladesh has a coastal zone covering an area of $47,201 \mathrm{~km}^{2}$ extending along the Bay of Bengal [2]. Bangladesh Forest Department started the afforestation program in 1966 in the coastal belt. The primary objectives of this plantation were to save lives and properties of coastal dwellers from the cyclone and tidal bores [3]. Approximately 190,000 ha of accreted lands were under coastal mangrove plantations till 2010 in Bangladesh [4]. Among them, Sonneratia apetala (Keora) had great success in growing, and Avicennia officinalis (Baen) ranked second of the coastal mangrove plantations [5]. S. apetala alone covered about $94.4 \%$, while A. officinalis accounted for $4.8 \%$ of the total established mangrove plantations [6].

WB [7] identified four key types of primary physical effects as crucial vulnerabilities in the coastal areas. These are - saline water intrusion, drainage congestion, extreme weather events, and change in coastal morphology. It raised a total of $5017 \mathrm{~km}$ of embankments throughout the coastal region [8]. However, the levees are under threat due to global warming and its impact on sea-level rise. To reduce the effects of climate change, it needs to develop sustainable forests along 
the coastal belt of Bangladesh. Mangrove afforestation is a soft adaptation measure that has significantly contributed to reducing the mortality of lives and properties against tropical hazards of cyclones and storm surges in the coastal areas [9]. Carbon storage in the forest ecosystem involves numerous components, including biomass carbon and soil carbon. The total ecosystem carbon is large and in dynamic equilibrium with its environment.

Because of the significant areas involved at the regional or global scale, forest soils play an essential role in the carbon cycle [10]. The potential of carbon sequestration in Annex I (developed or industrial economics) countries was estimated at 101 $\mathrm{TgCyr}^{-1}$ by 2010 and $503 \mathrm{TgCyr}^{-1}$ by 2040. Similarly, the potential of carbon sequestration in forest biome of Annex II (developing or industrializing economies) countries was at $69 \mathrm{TgCyr}^{-1}$ for 2010 and $200 \mathrm{TgCyr}^{-1}$ for 2040 . Also, the potential of the agroforestry system was at 12 and $17 \mathrm{TgCyr}^{-1}$ for 2010 and 2040, respectively, in Annex I countries and 14 and $28 \mathrm{TgCyr}^{-1}$ for 2010 and 2040, respectively, in Annex II countries. Therefore, the total global potential of carbon sequestration in forest biomes was at $196 \mathrm{TgCyr}^{-1}$ in 2010 and $748 \mathrm{TgCyr}^{-1}$ by 2040 [11].

The amount of carbon stored varies significantly among vegetation types, salinity zones, and vegetation functional attributes. The forest types with the dominant Sundri (Heritiera fomes), store more ecosystem carbon $\left(360.1 \pm 22.71 \mathrm{tCha}^{-1}\right)$ than another vegetation type $[8,12]$. The freshwater zone shows the highest ecosystem carbon stock $\left(336.09 \pm 14.74 \mathrm{tCha}^{-1}\right)$, followed by moderate and robust salinity zones [12]. After reviewing all of the research results written above, the present study found that- many studies estimated soil carbon stock in natural forests, plantations, secondary forest, agricultural land, and grassland all over the world. However, the measurement of soil organic carbon and its stock in coastal afforestation sites in Bangladesh is very few. However, if all of the forest areas, as mentioned by Miah et al. [13], can be appropriately managed and enriched shortly, Bangladesh will possess an excellent atmospheric carbon sequestrated country. The 
global storage of carbon in soils, the most abundant carbon pools of terrestrial ecosystems, two or three times larger than the carbon pool of vegetation [14].

There are different methods available for estimating soil organic carbon. Wet Oxidation (WO) and Loss On Ignition (LOI) are the conventional methods to determine Soil Organic Matter (SOM) and Soil Organic Carbon (SOC). With increasing interest in soil carbon sequestration to mitigate the greenhouse effects, there is a need to find out more accurate methods for determining SOC and SOM towards the purpose of international carbon trading. Measuring organic carbon stock of coastal afforestation by the WO and the LOI and showing the comparative result of two methods was the primary objective of this study. The other specific objectives of the study were to identify the structure and growing stock and to quantify the carbon sequestration in the soils of the coastal afforestation sites.

The study conducted its attempts in the coastal afforestation sites of Chittagong from February to June 2017. The studied area consists of Sitakunda Range at Sitakunda Upazila under Chittagong coastal afforestation division. The total area of coastal plantation under Sitakunda coastal afforestation range is 3830.16 ha. Sitakunda Upazila lies between $22^{\circ} 30^{\prime} \mathrm{N}$ to $22^{\circ} 54^{\prime} \mathrm{N}$ latitude and $91^{\circ} 27^{\prime} \mathrm{E}$ to $91^{\circ} 45^{\prime} \mathrm{E}$ longitude [15]. Sitakunda Range comprises of Bansbaria beat, Bhaterkhil beat, Bogachattor beat, and Bagkhali beat (pers.comm.).

Among the four beats, Bogachattor beat is the representative of the study for its immense success in mangrove plantation. The study area is about 6 kilometers away from Boro Dargar Hat, Sitakunda. In the study area, the Forest Department started the plantations on a newly accreted coastal land since 1966. The land surface is flat, stable, and muddy. The area is inundated twice a day by the saline water of the sea and subjected to heavy siltation. During the dry season, the upper part of this coastal land remains dry, and the sea-facing lands get inundated twice a day. The area is typically subtropical, with a long dry season extending from 
September to April. A view reflecting the location of Bogachattor forest beat under coastal forest division in Chittagong appears in figure 1.

The study adopted a random sampling technique to select the sample afforestation sites. Firstly, it figured out tree species richness and diversity in the representative samples. Secondly, it determined the distribution of the diameter (dbh) and the total height class of the tree species. The study considered the three frequently planted tree species, Sonneratia apetala (Keora), Avicennia officinalis (Baen), and Excoecaria agallocha (Gewa). The official record of the Bogachattor forest beat helped identify the frequently planted tree species in the study area. It measured all the trees of more than $5 \mathrm{~cm}$ dbh for the study. The age of the stands of these three species was 20 years.

A structured data sheet recorded data on diameter at breast height (dbh) and a total height of trees. It measured dbh with slide caliper and diameter tape and measured the total height of trees with Shunto Clinometer. It sampled soil with fixed volume metallic soil core to measure bulk density and organic carbon. The principal activities of this research were to analyze the soil organic matter (\%) and soil organic carbon (\%) along with the estimation of the soil organic carbon stock $\left(\mathrm{tCha}^{-1}\right)$. The vegetation study was the minor activities of this study. It only helped understand the influencing factor of the soil organic carbon stock. 


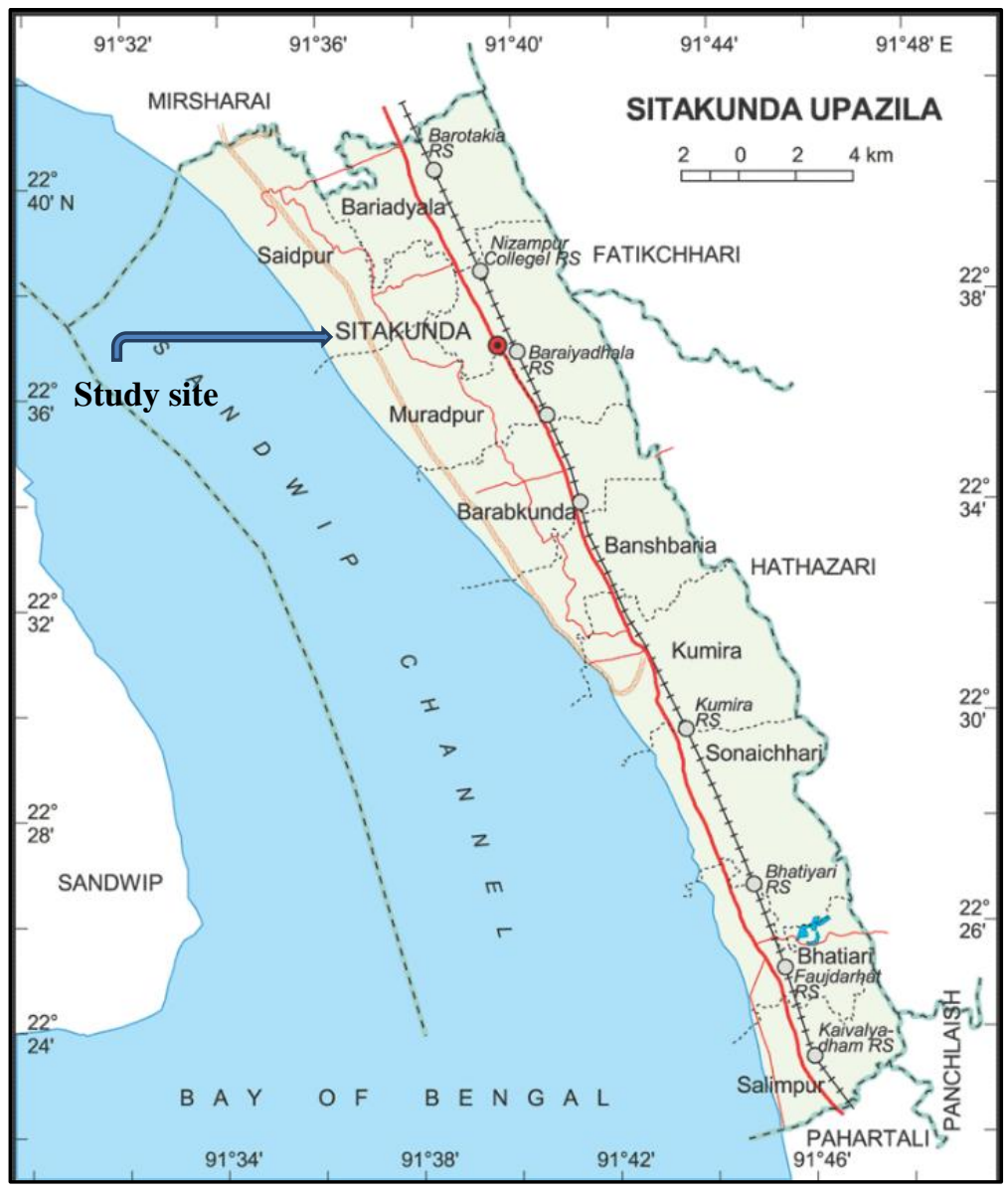

Figure 1. Location of Bogachattor forest beat in Sitakunda under the Chittagong coastal forest division.

To estimate the carbon contents in the soils, it collected soil samples from all the selected plots. Soil sample plot was a sub-sample of vegetation plot. It was approximately in the middle of the vegetation plot. It analyzed the soil samples in the soil laboratory of the University of Chittagong for analyzing SOM and SOC. 
It studied a total of 30 permanent sample square-plots from the forest beat. The study determined the sample size using the formula of Cochran [16]. The decision on the size of each plot was $10 \mathrm{~m} \times 10 \mathrm{~m}$. The size of the plot followed the criteria described by Curtis and Marshall [17] and Wiegert [18]. For a convenient demarcation of the boundary of each plot, the study involved a nylon rope of $100 \mathrm{~m}$ length.

It recorded the center of the plot as the global coordinates (latitude, longitude) assisted by the GPS (Global Positioning System). The distribution of the sampled plots ranged from latitude $20^{\circ} 40^{\prime} 11.8^{\prime \prime} \mathrm{N}$ to $22^{\circ} 40^{\prime} 25.8^{\prime \prime} \mathrm{N}$ and longitude $91^{\circ} 33^{\prime} 09.2^{\prime \prime} \mathrm{E}$ to $91^{\circ} 33^{\prime} 38.9^{\prime \prime} \mathrm{E}$.

Bird-eye view of the study area, indicating the waypoints of 30 permanent plots and whole covered area by connecting the broader waypoints, is in figure 2 .

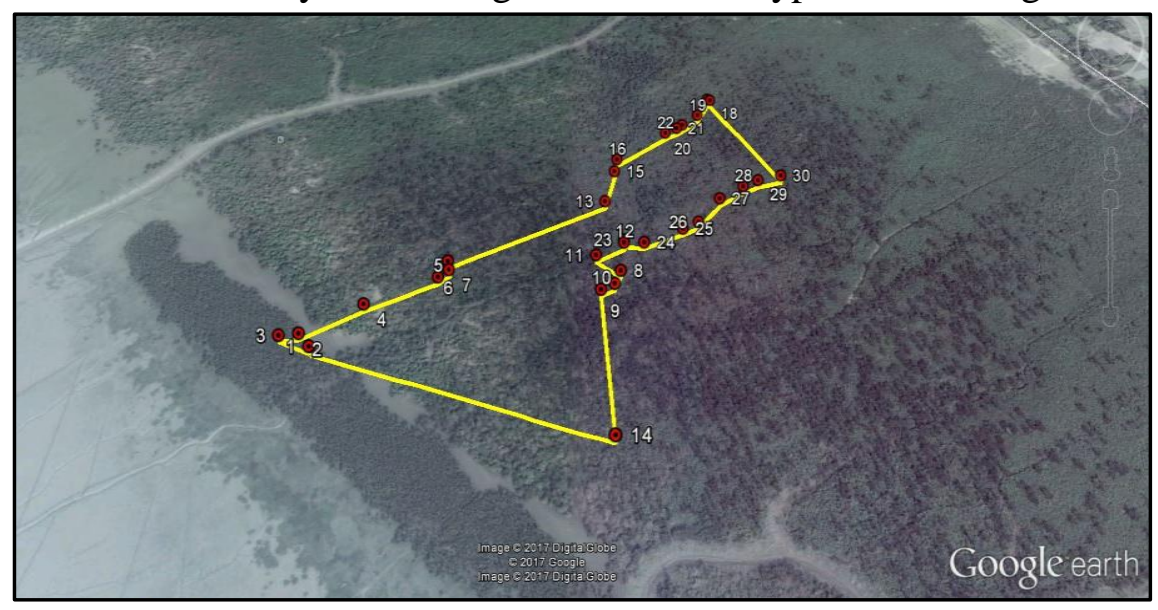

Figure 2. Demarcated whole study area in the Bogachattor forest beat connecting the boundary waypoints under the Chittagong coastal forest division (Source and time were Google earth and 17 July 2017, respectively).

It recorded height and diameter at breast height ( $\mathrm{dbh})$ of all the tree species, of which $26 \%$ trees were of the species S. apetala, $32 \%$ of A. officinalis, and $42 \%$ of 
E. agallocha. Also, it determined the species wise distribution of dbh and total height class of these trees. For this, it put three cut-points in all values of dbh and total height to make dbh and height classes based on equal percentile. Hence, it formed four height classes (m) as $\leq 5.0,5.1-10.0,10.1-15.0,15.0+$, and four dbh classes (cm) as $\leq 10.0,10.1-15.0,15.1-20.0$, and 20.0+. The study applied the SPSS statistical software along with the use of Microsoft Excel to analyze the data.

The study weighed the soil samples collected by the soil core in the field and then brought the samples to the soil laboratory for organic carbon measurement. It involved WO and LOI method for the determination of the soil organic carbon in the laboratory. This study describes the soil parameters in this paper, primarily derived from the LOI method. However, it further compares the selected soil values among the two methods. It collected three soil samples from 0-10 cm by the soil core of a known volume from each plot of a $1 \mathrm{~m}$ radius under the mother plot of vegetation study. Moreover, it then compounded the samples. Likewise, it collected the other three samples from the $0-30 \mathrm{~cm}$ soil depth. The study followed a systematic sampling method to collect the soil sample. It considered a random diameter line of the circle soil plot. Two samples were from the two last ends of the diameter line and one sample from the center. After taking a sample from the $0-10$ $\mathrm{cm}$, another sample was taken from the 11-30 cm soil depth from the same pit of soil. The soil sample was handled and stored following the basic standards of Carter and Gregorich [19].

For measuring organic soil carbon in WO method, the study followed the equation described by McLeod [20],

$$
\begin{aligned}
& \text { OC\% } \%[0.003 \mathrm{~g} \times \mathrm{N} \times 10 \mathrm{ml} \times(1-\mathrm{T} / \mathrm{S}) \times 100] \div \mathrm{ODW} \\
& =3(1-\mathrm{T} / \mathrm{S}) \div \mathrm{W} \\
& \text { Where, } \mathrm{N}=\text { Normality of } \mathrm{K}_{2} \mathrm{Cr}_{2} \mathrm{O}_{7} \text { solution } \\
& \mathrm{T}=\text { Volume of } \mathrm{FeSO}_{4} \text { used in sample titration }(\mathrm{mL}) \\
& \mathrm{S}=\text { Volume of } \mathrm{FeSO}_{4} \text { used in blank titration }(\mathrm{mL}) \\
& \text { ODW= Oven-dry sample weight }(\mathrm{g})
\end{aligned}
$$


$\mathrm{OM} \%=101[(\mathrm{~S} \div \mathrm{B})] \times 0.67$

Where, $S=$ Sample titration

$\mathrm{B}=$ Blank titration

For measuring organic soil carbon and organic matter in LOI method, the study followed the equations described by Ball [21].

$\% \mathrm{LOI}=\left(\mathrm{W}_{1} / \mathrm{W}_{2}\right) \times 100$

Where, $\mathrm{W}_{1}=$ Loss in weight

$$
\mathrm{W}_{2}=\text { Weight of oven-dry soil }
$$

Calculation of the percentage of carbon and organic matter followed the relationship below,

$\% \mathrm{C}=0.476 \times(\% \mathrm{LOI}-1.87)$

$\%$ Organic matter $=\% \mathrm{C} \times 1.72$

For measuring organic soil carbon, the following equation was used described by Pearson et al. [22].

Bulk density $\left(\mathrm{gm} / \mathrm{cm}^{3}\right)=$ mass $(\mathrm{gm}) /$ core volume $\left(\mathrm{cm}^{3}\right)$

$\mathrm{C}(\mathrm{t} / \mathrm{ha})=\left(\right.$ soil bulk density $\left(\mathrm{gm} / \mathrm{cm}^{3}\right) \times$ soil depth $(\mathrm{cm}) \times \mathrm{C} \times 100$

(C expresses as a decimal fraction, for example, 2.2\% expresses as 0.022 in the equation; bulk density expresses as $\mathrm{gm} / \mathrm{cm}^{3}$ )

The study compared the values of selected soil parameters, derived from the two methods for three tree species, by using two-way Analysis of Variance (ANOVA).

The dbh class $20.0+\mathrm{cm}$ and $10.1-15.0 \mathrm{~cm}$ were maximum having $72.7 \%$ and $69.2 \%$, respectively, in the height class $10.1-15.0 \mathrm{~m}$ of the tree species $S$. apetala (Table 1). The dbh class $10.1-15.0 \mathrm{~cm}$ and $\leq 10.0 \mathrm{~cm}$ were dominant in the height class 5.1- $10.0 \mathrm{~m}$ of the tree species A. officinalis having $92.9 \%$ and $80.0 \%$, respectively. Likewise, the dbh class $10.1-15.0 \mathrm{~cm}$ and $\leq 10.0 \mathrm{~cm}$ were dominant, having $88.2 \%$ and $81.0 \%$, respectively, in the same height class of E. agallocha. 
On the other hand, the dbh class $20.0+\mathrm{cm}$ was minimum, having $6.8 \%$ in the height class of $15.0+\mathrm{m}$ of the species $S$. apetala. Likewise, it noticed the least percentage $(2.1 \%)$ of the same dbh class and in the same height class of $A$. officinalis. For E. agallocha, the dbh class $\leq 10 \mathrm{~cm}$ was minimum having $3.8 \%$ in the height class 10.1-15.0 m.

The mean dbh and total height in the $S$. apetala plantation were $20.04 \pm 0.93 \mathrm{~cm}$ and $11.17 \pm 0.29 \mathrm{~m}$, respectively (Figure 3). These values for A. officinalis were $19.04 \pm 0.61 \mathrm{~cm}$ and $9.08 \pm 0.23 \mathrm{~m}$, respectively. E. agallocha plantation revealed dbh $9.55 \pm 0.21 \mathrm{~cm}$ and the total height of $6.90 \pm 0.14 \mathrm{~m}$, respectively, though the total number of individuals of this species was the highest (42\%).

Table 1. Height and dbh class distribution of coastal planted tree species in the Bogachattor forest beat under the Chittagong coastal forest division.

\begin{tabular}{llccccc}
\hline $\begin{array}{l}\text { Scientific name of the } \\
\text { tree species }\end{array}$ & $\begin{array}{l}\text { dbh class } \\
(\mathbf{c m})\end{array}$ & \multicolumn{5}{c}{$\begin{array}{c}\text { Height class }(\mathbf{m}) \\
(\boldsymbol{\%})\end{array}$} \\
\cline { 3 - 7 } & & $\leq \mathbf{5 . 0}$ & $\mathbf{5 . 1 - 1 0 . 0}$ & $\mathbf{1 0 . 1 - 1 5 . 0}$ & $\mathbf{1 5 +}$ & Total \\
\hline Avicennia officinalis & $\leq 10$ & 10.0 & 80.0 & 10.0 & - & 100 \\
& $10.1-15$ & - & 92.9 & 7.1 & - & 100 \\
& $15.1-20$ & - & 64.5 & 35.5 & - & 100 \\
& $20+$ & - & 47.9 & 50.0 & 2.1 & 100 \\
\hline Excoecaria agallocha & $\leq 10$ & 15.2 & 81.0 & 3.8 & - & 100 \\
& $10.1-15$ & - & 88.2 & 11.8 & - & 100 \\
& $15.1-20$ & - & 50.0 & 50.0 & - & 100 \\
& $20+$ & - & - & - & - & - \\
\hline Sonneratia apetala & $\leq 10$ & 15.4 & 53.8 & 30.8 & - & 100 \\
& $10.1-15$ & 7.7 & 23.1 & 69.2 & - & 100 \\
& $15.1-20$ & - & 33.3 & 50.0 & 16.7 & 100 \\
& $20+$ & - & 20.5 & 72.7 & 6.8 & 100 \\
\hline
\end{tabular}

Though the number of individual trees of $S$. apetala was the lowest (26\%), the highest value of mean $\mathrm{dbh}$ and total height were in the $S$. apetala plantation. The 
number of individual trees was the highest in E. agallocha plantation (42\%) followed by A. officinalis plantation (32\%). However, E. agallocha retained the lowest values of the mean dbh and total height.

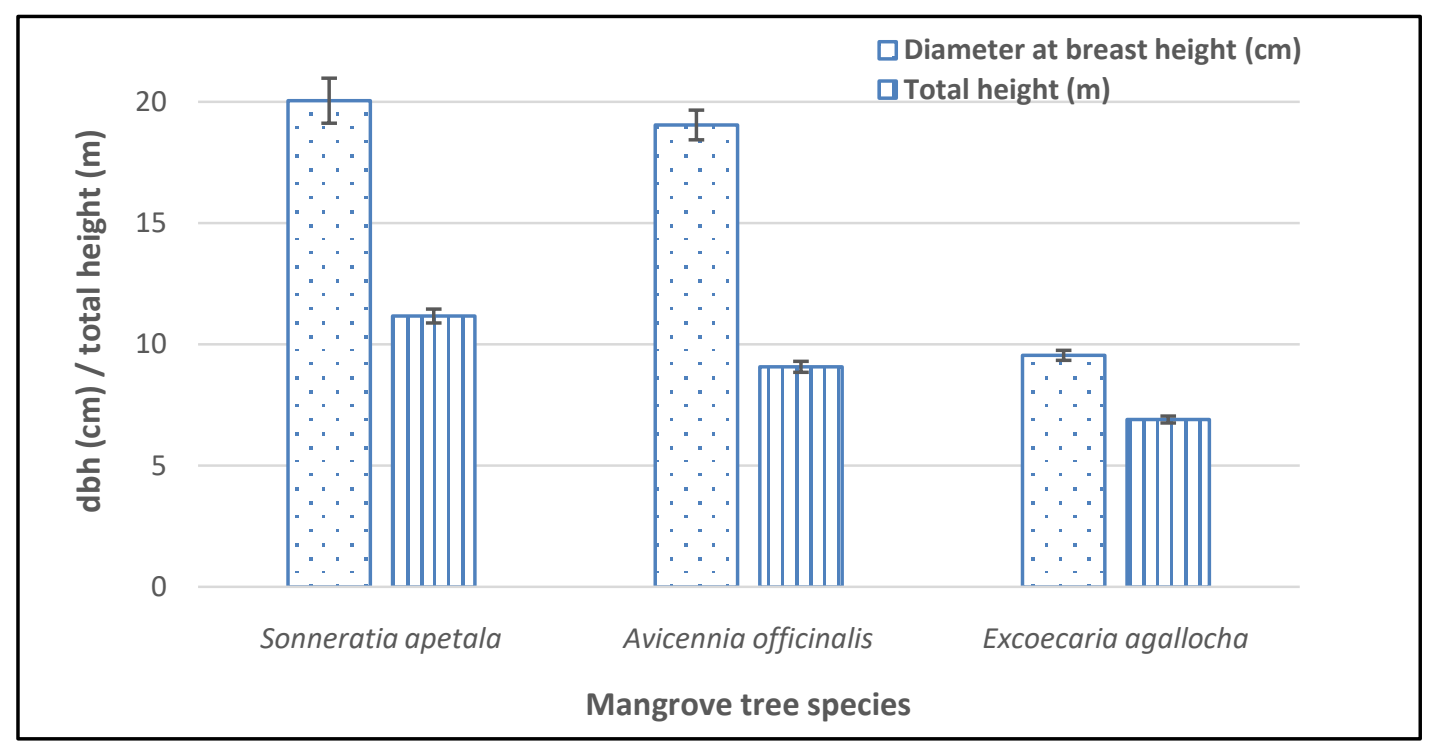

Figure 3. Diameter at breast height $(\mathrm{dbh})$ and total height observed in the plantation of the Bogachattor forest beat under the Chittagong coastal forest division.

Soil organic carbon was the highest, $2.15 \pm 20 \%$ in the E. agallocha plantation, followed by $S$. apetala, $1.89 \pm 14 \%$. Likewise, it found the highest organic matter in

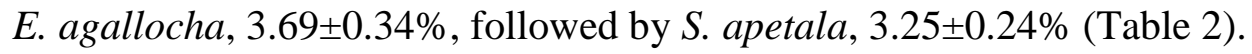

Based on the soil organic carbon percentage and the soil depth measurement, the organic carbon was the highest, $35.76 \pm 2.57 \mathrm{tCha}^{-1}$ upto $10 \mathrm{~cm}$ soil depth and $107.29 \pm 7.71 \mathrm{tCha}^{-1}$ upto $30 \mathrm{~cm}$ soil depth, in the E. agallocha, followed by $32.98 \pm 2.72 \mathrm{tCha}^{-1}$ upto $10 \mathrm{~cm}$ soil depth and $98.95 \pm 8.15 \mathrm{tCha}^{-1}$ upto $30 \mathrm{~cm}$ soil depth, in the S. apetala plantation (Table 3). 
Table 2. Comparison of soil organic carbon and soil organic matter, between the WO and the LOI method, in the coastal afforestation sites of the Bogachattor forest beat under the Chittagong coastal forest division.

\begin{tabular}{lcc|cc}
\hline \multirow{2}{*}{$\begin{array}{l}\text { Scientific name of } \\
\text { the tree species }\end{array}$} & \multicolumn{2}{c|}{ Organic carbon (\%) } & \multicolumn{2}{c}{ Organic matter (\%) } \\
\cline { 2 - 5 } & WO & LOI & WO & LOI \\
\hline Avicenniaofficinalis & $0.56 \pm 0.01^{*}$ & $1.75 \pm 0.13$ & $0.97 \pm 0.01$ & $3.00 \pm 0.23$ \\
Excoecariaagallocha & $0.57 \pm 0.1$ & $2.15 \pm 0.20$ & $0.99 \pm 0.02$ & $3.69 \pm 0.34$ \\
Sonneratiaapetala & $0.58 \pm 0.13$ & $1.89 \pm 0.14$ & $1.00 \pm 0.02$ & $3.25 \pm 0.24$ \\
\hline
\end{tabular}

Notes: WO means Weight Oxidation, and LOI means Loss On Ignition / * Standard Error of Mean

Table 3. Comparison of soil organic carbon stock, between the WO and the LOI method, in the coastal afforestation sites of the Bogachattor forest beat under the Chittagong coastal forest division.

\begin{tabular}{|c|c|c|c|c|}
\hline \multirow[t]{2}{*}{$\begin{array}{l}\text { Scientific name of } \\
\text { the tree species }\end{array}$} & \multicolumn{2}{|c|}{$\begin{array}{c}\text { Soil organic carbon stock } \\
\left(\mathrm{tCha}^{-1}\right) \text { at } 0-10 \mathrm{~cm} \text { soil depth }\end{array}$} & \multicolumn{2}{|c|}{$\begin{array}{l}\text { Soil organic carbon stock }\left(\mathrm{tCha}^{-1}\right) \text { at } \\
0-30 \mathrm{~cm} \text { soil depth }\end{array}$} \\
\hline & WO & LOI & WO & LOI \\
\hline Avicennia officinalis & $9.90 \pm 0.18 *$ & $30.80 \pm 2.33$ & $29.70 \pm 0.55$ & $92.40 \pm 6.99$ \\
\hline $\begin{array}{l}\text { Excoecaria } \\
\text { agallocha }\end{array}$ & $9.73 \pm 0.23$ & $35.76 \pm 2.57$ & $29.18 \pm 0.70$ & $107.29 \pm 7.71$ \\
\hline Sonneratia apetala & $10.13 \pm 0.29$ & $32.98 \pm 2.72$ & $30.38 \pm 0.88$ & $98.95 \pm 8.15$ \\
\hline
\end{tabular}

Notes: WO means Weight Oxidation, and LOI means Loss On Ignition / * Standard Error of Mean

In all of the parameters, the study discussed above, the values of organic carbon of the LOI are more than the WO method. The highest value of organic carbon, organic matter, and carbon stock in LOI are $2.15 \pm 0.20 \%, 3.69 \pm 0.34 \%$, and 107.29 \pm 7.71t Cha ${ }^{-1}$ in E. agallocha plantation, respectively (Table 2 and Table 3). On the other hand, there are no significant differences among the three species for every parameter in the WO method. Again, the amount of organic carbon (\%) and organic matter $(\%)$ is meager. However, the soil of the present study area enriches with silty clay and clay contents. 
Across three species compared in the WO and the LOI method, soil organic carbon (\%) and soil carbon stock were higher in the LOI method shown in table 2 and table 3. The estimation of soil organic carbon with the two methods was highly significantly different for both $p<0.05$ and $p<0.01$ level.

Both the WO and the LOI methods are the conventional methods to determine SOM and SOC [23]. To mitigate the greenhouse effects, the interest in soil carbon sequestration is increasing day by day. So, it needs to find out simple, cheap, and best method between the WO and the LOI method.

Barwari et al. [24] revealed that both methods were reliable, butthe LOI method was more accurate and suitable for soils with high clay contents and the calcareous soils. However, Santisteban et al. [25] reported that the WO method suits better for determining low levels of organic carbon in mineral soils. In contrast, LOI is suitable for determining higher organic matter levels, usually in organic soil.

The WO method is more time consuming and labor-intensive [24]. Secondly, this procedure creates hazardous Chromium $(\mathrm{Cr}$.) as a consequence of dichromate with concentrated sulfuric acid [26]. Thirdly, another disadvantageis that the WO method requires a correction factor that may introduce uncertainties for estimation of SOC [27]. Fourthly, some soil components can consume $\mathrm{H}^{+}$, the WO method that involves acid titration, and the back titration is not suitable for some soils, e.g., alkaline soils [27].

Many laboratories are transitioning from the WO method to the LOI method due to human health problems and environmental conditions [24]. Hence, many soil scientists involve the LOI technique to estimate SOC/SOM in agricultural soil, forest soil, sediments, and carbonate in sediments [21,26,28-30]. Another study demonstrated that compared with the WO method for SOC, the LOI method was reliable and could provide accurate estimates of SOC for arid soil [27]. The LOI technique is much suitable for determining SOC and SOM in forest soils and sediments and for measuring carbonate in sediment [31]. 
The values of SOC calculated by the LOI method derive the highest values in silty clay and clay soils because clay absorbs the water as the hygroscopic moisture between over-drying and ignition occurring [24]. Some other studies demonstratethat the LOI method can be precise if it is carried through cautiously [32].

Based on this evidence it has mentioned above, it is clear that the LOI method is the best method for the overall estimation of soil organic carbon stock and soil with high organic matter.

In the context of the present study, the highest carbon stock was in the Excoecaria agallocha plantation. With the increasing interest in carbon sequestration, there is a need to find out an accurate and straightforward method for determining soil organic carbon and soil organic matter. The study found that the WO method underestimated the soil carbon stock than that of the LOI method. This study also revealed thatthe LOI method is more appropriate than the WO method. Moreover, the result of the carbon stock found from the two methods is significantly different from each other.

\section{Acknowledgment}

The research project, with the reference 233/পওঊ7-23(14)/2015, was funded and supported by the University of Chittagong. 


\section{References}

[1] P. M. Cox, R. A. Betts, C. D. Jones, S. A. Spall and I. J. Totterdell: Nature, 2000, 408(6809), 184-187.

[2] M. R. Islam: "Where land meets the sea: a profile of the coastal zone of Bangladesh", 2004. The University Press Limited, Dhaka, Bangladesh, p. 317.

[3] S. Das and N. A. Siddiqi: "The mangroves and mangrove forests of Bangladesh", 1985. Bangladesh Forest Research Institute (BFRI), Chittagong, Bangladesh, p. 168.

[4] S. A. Islam, M. A. Q. Miah, M. A. Habib, M. G. Moula and M. G. Rasul: Bangladesh Journal of Forest Science, 2013, 32(2), 26-35.

[5] N. A. Siddiqi: "Mangrove forestry in Bangladesh", 2001. Institute of Forestry and Environmental Sciences, University of Chittagong, Bangladesh, Chittagong, Bangladesh, p. 201.

[6] N. A. Siddiqi and M. A. Khan: Journal of Tropical Forest Science, 2004, 16(2), 187-198.

[7] WB: "Bangladesh: climate change and sustainable development: Rural Development Unit, South Asia Region", 2000. The World Bank (WB), Washington, DC, USA, p. 138.

[8] M. M. Rahman, M. N. I. Khan, A. K. F. Hoque, and I. Ahmed: Wetlands Ecology and Management, 2015, 23(2), 269-283.

[9] P. Nandy and R. Ahammad: Navigating mangrove resilience through the ecosystembased adaptation approach: lessons from Bangladesh, in: D. J. Macintosh, R. Mahindapala, M. Markopoulos (Eds.), Sharing lessons on mangrove restoration, 2012. International Union for Conservation of Nature (IUCN), Gland, Switzerland with Mangroves for the Future, Bangkok, Thailand, Mamallapuram, India, pp. 243-254.

[10] R. Lal: Forest Ecology and Management, 2005, 220(1-3), 242-258.

[11] R. T. Watson, I. R. Noble, B. Bolin, N. H. Ravindranath, D. J. Verardo and D. J. Dokken: "IPCC special report on land use, land-use change, and forestry", 2000. Intergovernmental Panel on Climate Change (IPCC), Geneva, Switzerland, p. 222.

[12] M. Kamruzzaman, S. Ahmed, S. Paul, M. M. Rahman and A. Osawa: For. Sci. Tech, 2018, 14(1), 23-28.

[13] M. D. Miah, M. Y. Shin and M. Koike: "Forests to climate change mitigation: clean development mechanism in Bangladesh", 2011. Springer Science \& Business Media, Heidelberg, Germany, p. 98.

[14] W. H. Schlesinger and E. S. Bernhardt: "Biogeochemistry: an analysis of global change", 2013. Academic Press, Oxford, UK, p. 653. 
[15] BBS: "Population and housing census 2011", 2012. Bangladesh Bureau of Statistics Ministry of Planning Government of the People's Republic of Bangladesh, Dhaka, Bangladesh, p. 363.

[16] W. G. Cochran: "Sampling techniques", 2007. John Wiley \& Sons.

[17] R. O. Curtis and D. D. Marshall: "Permanent-plot procedures for silvicultural and yield research", 2005. U.F. Service, Olympia, WA, USA, p. 92.

[18] R. G. Wiegert: Ecology, 1962, 43(1), 125-129.

[19] M. R. Carter and E. G. Gregorich (Eds.), Soil sampling and methods of analysis, 2007. CRC press, NW, USA, p. 1263.

[20] S. McLeod: "Studies on wet oxidation procedures for the determination of organic carbon in soils", 1973. p. 73-79.

[21] D. F. Ball: Journal of Soil Science, 1964, 15(1), 84-92.

[22] T. Pearson, S. Walker and S. Brown: "Sourcebook for land use, land use change and forestry projects", 2005. Winrock International, Arkansas, USA, p. 57.

[23] A. Walkley and I. A. Black: Soil Science, 1934, 37(1), 29-38.

[24] V. I. H. Barwari, F. A. Hashim and B. H. Mohammed: Kufa Journal for Agricultural Science, 2017, 9(2), 292-306.

[25] J. I. Santisteban, R. Mediavilla, E. López-Pamo, C. J. Dabrio, M. B. R. Zapata, M. J. G. García, S. Castaño and P. E. Martínez-Alfaro: Journal of Paleolimnology, 2004, 32(3), 287-299.

[26] B. De Vos, S. Lettens, B. Muys, and J. A. Deckers: Soil Use and Management, 2007, 23(3), 221-229.

[27] G. Wang, D. Guan, M. R. Peart, et al.: Forest Ecology and Management, 2013, 310, 539-546.

[28] M. B. David: Communications in Soil Science and Plant Analysis, 1988, 19 (14), 1593-1599.

[29] M. E. Konen, P. M. Jacobs, C. L. Burras, B. J. Talaga and J. A. Mason: Soil Science Society of America Journal, 2002, 66(6), 1878-1881.

[30] A. L. Wright, Y. Wang and K. R. Reddy: Communications in Soil Science and Plant Analysis, 2008, 39(19-20), 3074-3083.

[31] W. E. Dean: Journal of Sedimentary Petrology, 1974, 44(1), 242-248.

[32] O. Heiri, A. F. Lotter and G. Lemcke: Journal of Paleolimnology, 2001, 25(1), 101-110.

The Chittagong Univ. J. Sc. Vol. 42(1), 2020 